\title{
Impact of the COVID-19 Crisis on the Regulation to Tourism in the Czech Republic
}

\author{
Lukáš Novotný \\ Jan Evangelista Purkyně University in Ústí nad Labem, Faculty of Arts, The Czech \\ Republic \\ lukas.novotny@ujep.cz \\ https://orcid.org/0000-0002-8115-6386 \\ Pavlína Pellešová \\ Silesian University in Opava School of Business Administration in Karviná, \\ The Czech Republic \\ pellesova@opf.slu.cz \\ https://orcid.org/0000-0002-2595-923X
}

Received: 28. 2. 2021

Accepted: 6. 4. 2021

\section{ABSTRACT}

The article deals with issues concerning the regulation of tourism during the Covid-19 crisis in the Czech Republic. Tourism is among the most affected economic sectors by the current pandemic. During the pandemic, the State compensated the financial losses of tourist guides, but such compensations were - according to the guides themselves - insufficient. The aim of the research was to find out how tourist guides see the Czech crisis legislation with regard to tourism and the legislative measures taken by the Czech Government and Ministry of Regional Development to support tourism. For such purpose, questionnaires were distributed to employees in tourism - guides, particularly. We examined their attitudes to the tourism legislation in the Czech Republic in connection with the pandemic situation as well as public administration. Next, in-depth interviews were conducted. On the one hand, the research revealed great interest of tourist guides in the legislation and the current situation in the Czech Republic. On the other hand, it showed a negative evaluation of the adopted legislative measures and crisis legislation. On the basis of the research, the most important aid factors were identified: financial aid, greater support from the State and municipalities, exemption of social security and health insurance payments, promotion of tourism and guide services, support in the form of upgrading skills and retraining. The empirical part of the research, which used the Chi-Square Test of Independence, pointed to a dependence between gender and the attitude related to the legislation knowledge, between gender and monitoring of the current situation in European legislation concerning tourism and tourist guides, and between gender and attitudes when evaluating the 
legislative measures adopted by the Czech Government and Ministry of Regional Development in relation to tourism support. At the end of the study, some recommendations are provided on how to improve the present situation.

Keywords: tourist guide, public administration, Covid-19, tourism, Czech Republic, management.

$J E L: H 7, K 4, Z 3$

\section{Introduction}

The COVID-19 pandemic is a genuine stress test for states around the globe (Aburumman, 2020; Wen et al., 2020; Romagosa, 2020; Hossain, 2021). The economic crisis caused by the COVID-19 pandemic has also painfully affected tourism in the Czech Republic and all related sectors. For example, Czech spa industry has experienced a decline of sales by 60 percent during the first five months of 2020 and reports loss worth hundreds of millions CZK. Long-distance flights, bringing almost 0.5 million tourists from China and the US last summer disappeared. It is not purely the case of the Czech Republic (CR), but it is obvious that the field of tourism belongs to the economic sectors most affected by the current pandemic (Skare, Soriano and Porada-Rochoń, 2020). Rebuilding tourism is a priority but the sector must become more sustainable and resilient in the future. Tourism continues to be one of the sectors hit by the coronavirus pandemic in the hardest way and the outlook remains highly uncertain. According to the OECD, tourism has fallen in 2020 by about $80 \%$ (OECD, 2020). The situation was and still remains unfavourable and the chances for near economic recovery аге pessimistic. The measures taken against the Covid-19 have brought (not only) to the Czech Republic fewer tourists and the decline of $90 \%$ in entrepreneurship in the tourism sector (ČT 24, 2020). This drop has also been given by the fact that 10.8 million tourists were accommodated in the Czech Republic, which is the year-to-year drop of $51 \%$. There were nearly $3 / 4$ (three quarters) fewer guests from abroad. The tourists spent 31.2 million nights in hotels, boarding houses or campsites, a year-to-year fall of 45.3 percent (Idnes, 2021). This had and continues to have the crucial impact on travel agencies, tour operator agencies, guides working in tourism, consequently, on the follow-up industries such as hotel management and gastronomy as well.

In this study, we want to concentrate on segment tourism sector, particularly, on tourist guides and how our State helped them and compensated them for their financial losses during the pandemic. The survival of businesses throughout the tourism ecosystem is at risk without continued government support and although governments have taken impressive actions to cushion the blow to tourism, to minimise job losses and to build recovery in 2021 and beyond, more needs must be met, and in a more co-ordinated way (OECD. 2020). In the Czech Republic, there were 4500 people working as tourist guides in the first half of the last year (Týden.cz, 2020). Especially during the first pandemic 
wave of the Covid-19, some errors and failings occurred in terms of the support for tourist guides provided by the Czech Government. These mistakes, made considerably uncertain not only the guides themselves, but also their associations (Irozhlas.cz, 2020). How significant these faults were and what the attitude of the guides themselves concerning the compensation from the State for the loss of their revenues is, will be the subject matter of this study. In the process, we will focus on political, administrative and communication tools regarding this support. By now, we have learned from the Czech Republic Guide Association statement that the help in the form of compensations of the losses came too late, which has already been manifested negatively and is to be pointed out in the following chapters (Asociace průvodců, 2020).

Merely in the field of travel agencies and tour operator agencies, the whole $12 \%$ of these (over 100 market economy operators) halted their business activities by the end of October 2020. The number of the shut-down businesses in case of tourist guides has not been at our disposal yet, however, the seasonal nature and the clustering of international tourism into the particular urban areas of the Czech Republic - predominantly Prague, West-Bohemian spa areas, Český Krumlov or Brno and areas connected to this, the accumulation of tourism industry staff, makes it more difficult for the tourist guides to find their potential place in the labour market if they were to leave their position. Of course, the government, by means of their subsidy scheme Covid-Tourism, tries to aim at the tourist guides' professional development so that the guides are not dependent on one and the only market segment, but could find their place even in the different fields. The vision of the Ministry of Regional Development's (MMR) authority is to find provisional employment with respect to language-knowledge, Czech language or history, for instance in the education system. However, the existing practice does not comply with that (MMR, 2020).

The study is designed as follows. Firstly, the attention will be paid to the current knowledge we have about risk-management in the tourism sector in relation to the catastrophes, mainly with various health pandemics. We have some of not utterly complete findings at our disposal, which are obviously not transferable to the present-day situation concerning the Covid-19, nevertheless, it is possible minimally, to draw certain trends from them. In the next chapter, then, we will already deal with the Czech Republic and the help directed to travel agencies, tour operator agencies and tourist guides. We will highlight that even though the pandemic in the Czech Republic had broken out as early as in March 2020, the aid scheme was declared no sooner than in September 2020. This caused strong discontent of tourism entities together with tourist guides, on whom we will concentrate here. These reported only $10 \%$ of the usual procurements (Asociace prưvodcư, 2020).

The research was both, quantitative and qualitative. In other words, a questionnaire survey and subsequently, additional in-depth led interviews. The research was carried out with respect to the current pandemic situation, mainly in the electronic form (in case of questionnaires), or by phone and partly in person too (in case of additional interviews). It is necessary to add that during 
the last year, apart from pandemic measures, rather a crucial change of legislation was made - in accordance with a new Law No 159/1999 Coll. provision, tourist guide activity can be performed only by a person to whom the Czech Tourist Guide Certification Card has been issued.

In the empiric part we concentrated on the quantitative research among tourism employees, namely tourist guides during the Covid-19 pandemic period. We examined the guides' opinions on the legislation in the field of tourism $(T)$ in relation to the pandemic situation and public administration. The goal of the research was to find out how the tourist guides viewed Czech Government's crisis legislation for the tourism sector and the legal measures taken by them and The Ministry of Regional Development in terms of the tourism support provided. This included ad hoc, short-term primary information research of the descriptive, explorative and monitoring type focused on the facts. The research methods used for this study was: accumulation of the data by means of primary research techniques, a data analysis based on the secondary information sources, and statistical hypotheses-testing with the Pearson Chi-square test. The research was both, quantitative and qualitative, in other words - the questionnaire survey and subsequently, additional in-depth led interviews. The research was carried out with respect to the current pandemic situation, mainly in the electronic form (in case of questionnaires), or by phone and partly in person too (in case of additional interviews). The interviewing has been realized by means of personal questioning in the form of questionnaire in the written as well as electronic version. The final amount of the research sample gathered was given by the guides' willingness to participate in the research.

\section{Literature review}

Scientific literature offers a wide range of studies about risk management in the tourism field (Boksbergera, Biegerb and Laesserb, 2007; Fangnan et al., 2016; Bezkhlibna, But and Nykonenko, 2018). It is essential to mention that exactly the question of risk is in Tourism the key one (Fodoudi, Tabaghdehi and Marvi, 2021; Rosselló, Becken and Santana-Gallergo, 2020). There are also the studies dealing with risk management in the sector of health risks, together with the fear of infectious viruses which would disrupt the operators' enterprises in Tourism or which could have a negative impact on the health of tourists in the various destinations (Cartwright, 2000). We know about the effects of the pandemic SARS (Chen, Law and Zhang, 2021), for example the fact that an epidemic SARS outbreak in 2003 led to the drop of $29 \%$ in hotel stock prices in Taiwan (Chen, Jang and Kim, 2007). Similar results were calculated in other countries too (Chen, 2011). The research in this field showed that the relation of Tourism industry towards unexpected events was accentuated nowadays as a research topic (Law, 2006; Floyd, Gibson, Pennington-Gray and Thapa, 2004; Hall, 2010; Hajibaba, Boztuğ and Dolnicar, 2016; Novelli, Burgess, Jones and Ritchie, 2018; Modlin, Alderman and Gentry, 2011), however, far less attention has been paid to the Tourism and health risks relationship (Zopiatis, Savva and Lambertides, 2019). 
We know that the COVID-19 pandemic, labelled as a "black swan event", has been causing severe damage to the economy from a disease outbreak (Pak et al. 2020; Niewiadomski, 2020; Gössling, Scott and Hall, 2020). The range of this disease forced the WHO to declare the Covid-19 on 11 March 2020 a pandemic. Nowadays, the virus has been spread all over the world, exhibiting itself in various parts of the globe with different intensity (Pappas and Glyptou, 2021; Sikiru and Salisu, 2021). Crucial is implementation of restrictive measures, together with restrictions on free movement of persons, curfews and bans on travelling. This has resulted in closure of borders for tourists and the necessity of social distancing. Therefore, the Covid-19 has caused a huge economic recession (Eichenauer and Sturm, 2020; Chang, McAleer, and Ramos, 2020; Kock et al., 2020), the consequences of which can be predicted only with difficulty, though they can be worse than existing pandemic (UNWTO, 2020a). In fact, prohibitions on tourism already have and from now on, will have an impact on the world-wide tourism and it will affect practically all of its types (Shek, 2021).

This has already been confirmed even by 'World Tourism Organization' which in the relation to this, invites the states to the 'reasonable' measurements implementation in order to support tourism and save the livelihood the people who earn their living in this field (UNWTO, 2020b). With regard to the Covid-19, the data and only slowly lessening pandemic are not favourable at all. Last year, the decline in the number of foreign tourists was of $70 \%$. Especially small firms are vulnerable; however, they ensure $80 \%$ of the world tourism. The consequences are obvious in all of the states, nevertheless, they are most vividly demonstrated in those countries that are dependent on tourism. According to 'The World Travel \& Tourism Council' (WTTC, 2020), based on the knowledge about previous pandemics, this field has been recovering slower than other economic sectors. The UNWTO, in this relation, appeals to states to transform tourism sector. For this 'restart', the UNWTO has determined 5 priorities: 1) to mitigate socioeconomic impacts on peoples' lives, particularly on employment of women and social security, 2) reinforce competitiveness and resilience, 3) support innovation and tourism digitalization, 4) strengthen sustainability and green growth oriented to natural undemanding resources and low-carbon-tourism, 5) coordinate partnerships for sector-transformation so as to achieve the Goals of Sustainable Development (UN, 2020).

According to the OECD, the main policy priorities that governments should pay attention to are:

- Restoring traveller confidence.

- Supporting tourism businesses to adapt and survive.

- Promoting domestic tourism and supporting safe return of international tourism.

- Providing clear information to travellers and businesses, and limiting uncertainty (to the extent possible). 
- Evolving response measures to maintain capacity in the sector and address gaps in support strengthening co-operation within and between countries.

- Building more resilient, sustainable tourism (OECD, 2020).

\section{State's role in helping the tourist industry}

The OECD also draws attention to the fact that a range of tourism professions should be financially supported in the Covid-19 pandemic. In particular, among these professions, tourist guides appear as well. It is possible to find information related to the importance of such implementations from both sides, the government and the public administration side, to compensate for 'gaps in provision' of these services. Thus, it indicates how crucial a role the state plays in the tourist guides' survival (Nhuyen and Thi, 2021; Toanoglou, Chemli and Valeri, 2021). It is in line with the WTTC appeal to governments to implement policies that would directly support the sector across the following three areas, namely:

- Protecting the Livelihoods of Workers: Financial help must be granted to protect the incomes of the millions of workers in a severe difficulty.

- Fiscal Support: Government must extend vital, unlimited interest-free loans to global Travel \& Tourism companies as well as the millions of small and medium-sized businesses as a stimulus to prevent them from the collapse. Governments dues and financial demands on the Travel \& Tourism sector need to be waived with an immediate effect for at least the next 12 months.

- Injecting Liquidity \& Cash: Cash flow assistance to support big and small players of the Travel \& Tourism sector is critical as well as to offer targeted support to severely affected industries within the sector (WTTC, 2021).

On 19 June 2020, the European Parliament voted on a resolution on transport and tourism in 2020 requesting a further action to support small and medium-sized enterprises hit by the crisis and funding to help the sector. MEPs said that the crisis should be considered as an opportunity to modernise tourism in the EU by making it environmentally friendly and socially responsible. Businesses and workers from the tourism sector already benefit from the EU measures taken in response to the Covid-19 crisis, including liquidity support, fiscal relief and an easing of state aid rules, as well as the temporary suspension of the EU rules on airports slots to avoid empty flights. To protect travellers, the EU has updated the guidelines on passenger rights and the package travel directive. It has also facilitated the repatriation of tens of thousands of Europeans stranded abroad, through the EU Civil Protection Mechanism. The EU measures to support the tourism industry complement and reinforce measures taken at the national level. The European Commission proposed on 4 September that the EU countries should coordinate their measures restricting free movement during the pandemic. The aim is to reduce uncertainty for travellers and businesses resulting from a wide range of diverging national rules (EU Parliament, 2021).

The support has the form of subsidised interest rates on loans, direct grants, and exemptions from the obligation to pay certain social contributions. Un- 
der the subsidised interest rates measure, the State support covers the reimbursements, on behalf of tour operators, of package tours cancelled because of the coronavirus outbreak. The aid in the form of direct grants will support companies operating in the tourism and cultural sector, which had to interrupt their activities due to the coronavirus outbreak (Poland). The exemption from the obligation to pay certain contributions will support companies active in the tourism and cultural sector (which have lost in Poland more than $80 \%$ of their revenues due to the outbreak). Hungary notified the following main modifications to this scheme: (i) the extension of the measure to an additional loan programme called the "Széchenyi Tourism Card", that is accessible to small and medium-sized enterprises (SMEs) active mainly in the tourism sector and it takes the form of an overdraft facility.

Tourism is a distinct service sector and the Czech Republic economy (Novotný, 2021). As for the data from 2019, there was 240,000 people employed in tourism and thus, created about 3\% of the GDP. In the Czech Republic, so-called 'self-employed', have relatively a high share in the overall employment-rate. If in 2018 , there were 240,000 people working in this sector, there were 41,500 self-employed ones (ČT21, 2021). In hotels, restaurants, private transport related to tourism, along with tour operators, cultural services and other businesses, there were $63.4 \%$ of men and 36.6 of women self-employed. According to various prognoses, it had been assumed that in 2020, tourism sector would at least confirm very good efficiency in both - national tourism supported by Czech household finances and in the incoming tourism sector, which recently, has been boosted by the sharp rise in the number of tourists from Asia.

Nevertheless, the reality was different: the last year showed due to the pandemic Covid-19, a considerable drop not only in the national tourism but also in already very low demand for tourist-guide services. Travel restrictions worldwide as well as in Europe have stopped traditional interest of foreign tourists to visit the Czech Republic, so the number of visits remained on the historic minimum for the whole year.

Travel agencies and operators recorded the losses on bad pre-payments for planned tours that had been sent at the beginning of the pandemic to their foreign partners, minimum of the tour packages were sold during spring and summer (in comparison with the previous seasons) and what is more, they had to give the money back to clients for the trips which could not have been organized. The array of tour operator agencies is also dependent on Incoming tourism which is in the deep fall. Furthermore, tourist guides happened to be in the crisis as well. They certainly, could have postponed their payments for social and health insurance till August, however, how, as 'The CR Guides Association' added: ,from September, they were forced to interrupt the business conducting since they had no chance to earn enough even for tax-payment from this year season.' The summer holiday time slowly comes to an end and together with that, and so do tourist guides. Under such existing conditions, there is no way to continue and the next peak season is yet far (Asociace průvodců, 2020). 
The Czech Government support came a bit late. The Government of Prime Minister Babiš did not approve the 'Covid Tourism' programme before 19 October 2020 (MMR, 2020). The programme ensured 500 billion CZK (19264 $\mathrm{mld}$. euros to support travel agencies, operators with the aim to boost the liquidity, save operation and keep offerings of existing services and work places. Although the draft regarding the Aid scheme was of course, consulted with professional associations operating in tourism - especially with the Czech Tourism Forum, the Travel Agency Association of Tour Operators and the Travel Agents of the Czech Republic, the Association of Czech Travel Agents, but from these in fact, there could be heard critique in unison that the support comes late. In the programme, there is a half of billion CZK and it will be possible to draw money till June 2021 (Novotný, 2021).

Travel agencies support includes maximum $2.75 \%$ of the planned revenues from the trips and tourism services sold that are the part of joined travel services for the year 2020. In case of tour operators, the subsidy has been counted with regards to the number of the tours. Particularly, 500 CZK (approx. 19, 2 EUR) for the trip cancelled due to the pandemic and purchased (tour contract made) within the period between 1 Dec 2019 and 1 October 2020, and for the stay in the spa cancelled if the facilities were shut down. Moreover, terms and conditions regarding the subsidizing of incoming tour operators have been laid down at 50,000 CZK (1926 EUR). The tourist guides support goes in two directions. The State compensates their revenue losses (the programme Antivirus), next, they can as a part of the programme Covid-Tourism, receive one-time financial support of 50,000 CZK (1926 EUR) on condition that they will provide specialized educational services (minimally 10 hours) for the schools founded by the state, district or a municipality, or if they provide further education or retraining courses accredited by the Ministry of Education, Youth and Sports with the purpose of work placement on the labour market (e.g. Pedagogical Minimum). If they meet not meet a single condition, they can receive one-time payment of 40,000 CZK (approx. 1541 EUR). The support should have had the positive influence on the sector as well as tourist guides' skills development so that when necessary, they would be able to find their work place in other fields - not dependent on incoming tourism (Novotný, 2021).

It is necessary to add that during the last year, apart from pandemic measures, rather a crucial change of legislation was made - in accordance with a new Law No 159/1999 Coll. provision, tourist guide activity can be performed only by a person to whom the Czech Tourist Guide Certification Card has been issued. The Ministry of Regional Development issues two level-types of National Tourist Guide Certification Cards. To receive the first one, only registration is required while for the second level, professional qualification is expected given by corresponding education. Tourists themselves can choose how professional their guide should be necessary for them. This step responds to a long-term pressure of guides on regulation of their activity so as to eliminate existence of imposters and unqualified guides known especially in Prague. In addition to that, the Government of the Czech Republic approved the MMR's proposal to exempt guides from paying 1,000 CZK (38,5 euro) fee for the cer- 
tification card necessary their jobs from March. It is another way how to help tourist guide providers affected by the Coronavirus crisis. Thus, their already worrying financial situation linked to the reduction of their activity caused by the Covid-19, will not even deteriorate.

\section{Research methods}

The study tries to respond to the question: 'How the tourist guides themselves perceive the Government aid' during the Covid-19 pandemic period.

The reason why we have selected tourist guides as a target group from the field of sole-traders in tourism was to get opinions of one significant group conducting the business in tourism and hardly hit by the pandemic Covid-19. We have addressed respondents with the help of the Czech Republic Guide Association The survey took place last year in November and December. We examined their attitudes to legislation in tourism in connection to the pandemic situation and in relation to public administration. The aim of the research was to learn how guides evaluated the crisis legislation of the Czech Government in tourism and their and the MMR's legislative measures in the scope of support from the CR.

Research methods included data-gathering by means of primary research techniques, the data analysis available from secondary information sources and statistical hypotheses-testing using the Pearson Ch-Square Test. Inquiring was realized by questionnaires with the preference of the electronic form, but a part of questionnaires was received in the written form as well. The research sample of guides formed 196 respondents of different age groups, sex and length of practical training. The most of respondents were aged 61 and more (30\%), 24\% aged between 41 and 50 and 4\% aged 51-60, 18\% aged 31-40 and approximately 4\% aged 21-30. Mostly, the respondents (70\%) had university education, a quarter of them then, high-school education with the Maturita exam and $2 \%$ had high-school or other education, minority were men (32\%). As for the length of practical training, this differed, the most of respondents had $21-31$ years of experience (31\%), less than 9 years (28\%) and identically, approx. one fifth, had from 11-20, and 31 and above, years of experience. The respondents were from the whole of the $C R$, the most of them from Prague (53\%).

Besides questionnaires, we have conducted 20 intensive interviews as an additional technique. These were structured, questions formulated similarly as in the case of questionnaires as we tried to achieve a deeper knowledge of the guides' attitudes. Interviewer's handbook was first tested out and subsequently, interviews were carried out so as to guarantee respondents' anonymity.

With respect to objectives defined, research questions have been determined (RQ1-RQ3, see details below) as well as hypotheses (found below). This Pearson Chi-Square Test has been used to show relation between respondents' sex and the opinion on the factors examined. By means of the Independence 
Test (examining relationship between two quantitative variables, the existence of dependence has been tested at the significance level $a=0,05$.

In accordance with the questions, hypotheses have been formulated and the Pearson Chi-Square Test has been applied for their statistical testing. By means of the Chi-Square Test, correlation and existence of dependence between tourist guides' opinions on the problematic of legislation in the time of the pandemic and current development concerning tourism in the Czech Republic and in Europe and sex of respondents have been scrutinized. Dependence between the factors stated and education could not be determined because the conditions of figures expected have not been met. The research questions, statistical hypotheses and evaluation of hypotheses with the use of the Pearson's coefficient on the significance level $a=0,05$ have been identified. Expected observation values based on the mathematical relationship (1) and (2), values ni. and n.j, are expressed as a count of all of particular observations.

$$
\begin{aligned}
& e_{i j}=\frac{n_{i * *} n_{j}}{n}, \\
& n_{i .}=\sum_{j=1}^{S} n_{i j} \quad n_{\cdot j}=\sum_{i=1}^{r} n_{i j},
\end{aligned}
$$

The condition for acceptance of a hypothesis is that distribution is less than $20 \%$ of the values expected less than 5 and none of expected values should not be lower than 1.

RQ1: Are guides familiar with the legislation related to tourism and tourist guides in terms of measures connected to the pandemic crisis Covid-19?

Hypothesis $\mathrm{H}_{0}$ : There is no dependence between sex and being familiar with the legislative regarding tourism and guides.

Alternative hypothesis $\mathrm{H}_{1}$ : There is a relationship between sex and being familiar with the legislation regarding Tourism and guides.

For verification of the hypotheses on in/dependence between sex and the opinion that respondent is familiar enough with the legislation regarding to tourism and guides in times of the pandemic Covid-19, the Pearson ChiSquare Test has been used. Frequencies observed and expected which the test compares, are shown in Table 1.

Based on addends for testing criteria, Pearson Chi-Square (15,48 see Table 2) has been calculated, furthermore, the critical value on significance level a $=0,05$ and degree of freedom which is equal to the value $(r-1)(s-1)=4$. From the results it is clear that Chi-Square is higher than critical value $(15,48>9,49)$, also $\mathrm{p}$-value is lower than significance value a $(0,0038<0,05)$. On the basis of these findings, we reject the null hypothesis on independence, however, we accept $\mathrm{H} 1$ hypothesis: there is dependence between sex and attitude concerning familiarity with the legislation. One of the possible calculations of critical value is application of the Microsoft Excel CHINV function. 
Impact of the COVID-19 Crisis on the Regulation to Tourism in the Czech Republic

Table 1: Frequencies observed and expected

\begin{tabular}{|l|r|r|r|r|r|r|}
\hline \multicolumn{7}{|c|}{ Observed frequencies - Eij } \\
\hline & \multicolumn{1}{|c|}{ yes } & rather yes & cannot tell & rather no & no & Total \\
\hline women & 24 & 90 & 0 & 16 & 4 & 134 \\
\hline men & 12 & 34 & 6 & 6 & 4 & 62 \\
\hline total & 36 & 124 & 6 & 22 & 8 & 196 \\
\hline \multicolumn{7}{|c|}{ Expected frequencies - Qij } \\
\hline women & 24,61224 & 84,77551 & 4,10204082 & 15,04082 & 5,469388 & 134 \\
\hline men & 11,38776 & 39,22449 & 1,89795918 & 6,959184 & 2,530612 & 62 \\
\hline total & 36 & 124 & 6 & 22 & 8 & 196 \\
\hline
\end{tabular}

Source: authors

Table 2: Addends for test criteria (Eij-Qij)²/ Qij

\begin{tabular}{|l|c|r|r|r|r|r|}
\hline & yes & rather yes & cannot tell & rather no & no & total \\
\hline women & 0,02 & 0,32 & 4,10 & 0,06 & 0,39 & 4,90 \\
\hline men & 0,03 & 0,70 & 8,87 & 0,13 & 0,85 & 10,58 \\
\hline total & 0,05 & 1,02 & 12,97 & 0,19 & 1,25 & $\mathbf{1 5 , 4 8}$ \\
\hline
\end{tabular}

Source: authors

RQ2: Do guides monitor current development in Czech and European legislations regarding to tourism? Two questions have been raised.

Hypothesis $\mathrm{H}_{0}$ : There is no dependence between sex and monitoring of current development in Czech legislation regarding of tourism and tourist guides.

Alternative hypothesis $\mathrm{H}_{1}$ : There is relationship between sex and monitoring of current development in Czech legislation regarding of tourism and tourist guides.

After the hypothesis verification on dependence, the Pearson Chi-Square $(2,37989)$ has been calculated and next, critical value on significance level $a=0,05$ and a degree of freedom which is equal to the value $(r-1)(s-1)=2$. The results indicate that Chi-Square is lower than critical value $(2,37989<$ $5,991465)$, thus, the null hypothesis cannot be rejected. We accept $\mathrm{H} 1_{0}$ hypothesis on independence, however, the condition has been determined: more than $20 \%$ of expected values is lower than 5 . (2 values, Tab 3). Hence, the dependence has not been verified. 
Table 3: Expected frequencies

\begin{tabular}{|l|r|r|r|r|}
\hline & \multicolumn{1}{c|}{ yes } & rather yes & \multicolumn{1}{c|}{ no } & \multicolumn{1}{c|}{ Total } \\
\hline women & 72,47 & 60,16 & 1,37 & 134,00 \\
\hline men & 33,53 & 27,84 & 0,63 & 62,00 \\
\hline total & 106,00 & 88,00 & 2,00 & 196,00 \\
\hline
\end{tabular}

Source: authors

Hypothesis $\mathrm{H}_{2}$ : There is no dependence between sex and monitoring of current development in European legislation regarding tourism and tourist guides.

Alternative hypothesis $\mathrm{H}_{2}$ : There is dependence between sex and monitoring of current development in European legislation regarding tourism and tourist guides.

Based on addends for testing criterion, the Pearson Chi-Square $(15,48)$ has been calculated and critical value on significance level $a=0,05$ and a degree of freedom which is equal to the value $(r-1)(s-1)=3$. The results show that ChiSquare value is higher than critical value $(13,6572>7,814728)$, furthermore, p-value is lower than significance value a $(0,003411<0,05)$, based on these findings, we reject the null hypothesis on independence and accept hypothesis $\mathrm{H}_{1}$.

RQ3: How do the guides perceive Czech Government and the MMR's measures in terms of support from the State in times of the pandemic Covid-19? 2 hypotheses have been determined.

Hypothesis $\mathrm{H}_{0}$ : In the time of pandemic, there is no dependence between sex and attitude concerning evaluation of the government and MMR in terms of support of tourism field.

Alternative hypothesis $\mathrm{H}_{1}$ : In the time of pandemic, there is dependence between sex and attitude concerning evaluation of the government and the MMR in terms of support of Tourism field.

Based on addends for testing criterion, the Pearson Chi-Square $(2,37989)$ has been calculated, then, the critical value on the significance level $a=0,05$ and $a$ degree of freedom $(r-1)(\mathrm{s}-1)=4$.

The results show that Chi-Square value is higher than the critical value $(11,2303>9,487729)$, also the $p$-value is lower than significance value a $(0,024094<0,05)$, on these grounds, we reject the null hypothesis on independent variable and we accept $\mathrm{H} 11$ hypothesis, there is dependence between sex and the attitude concerning evaluating the government's and the MMR's measures in terms of support of tourism. 
Hypothesis $\mathrm{H}_{2}$ : There is no dependence between sex and influence of the crisis legislation of the Czech Government and the MMR in the time of the pandemic.

Alternative hypothesis $\mathrm{H}_{2}$ : There is, in the time of the pandemic, dependence between sex and influence of the Czech Government and the MMR.

Based on addends for the testing criterion, Pearson Chi-Square $(0,374951)$ has been calculated, followed by critical value on significance level $a=0,05$ and a degree of freedom which is equal to the value $(r-1)(s-1)=3$. From the results, it is clear that the Chi-Square value is lower than critical value $(0,374951<$ $7,814728)$, thus, the hypothesis cannot be rejected. We accept hypothesis $\mathrm{H} 2_{0}$ : dependence between sex and influence of crisis legislation of the Czech Government and the MMR in the time of pandemic has been verified.

Table 4 summarizes the results of analyses of dependencies between two variables by means of the Chi-Square Tests of Independence.

Table 4: Results of Chi square independence tests

\begin{tabular}{|l|l|l|l|l|l|l|l|}
\hline & $\begin{array}{c}\text { Chi- } \\
\text { Square }\end{array}$ & $\begin{array}{c}\text { degree } \\
\text { of } \\
\text { freedom }\end{array}$ & $\begin{array}{c}\text { critical } \\
\text { value }\end{array}$ & p-value & condition & $\mathbf{H}_{0}$ & $\begin{array}{l}\text { dependence/ } \\
\text { independence }\end{array}$ \\
\hline 1. & 15,48 & 4 & 9,49 & 0,004 & yes & reject & dependence \\
\hline $\mathbf{2 .}$ & 2,38 & 2 & 5,99 & 0,301 & no & accept & independence \\
\hline $\mathbf{3 .}$ & 13,66 & 3 & 7,81 & 0,003 & yes & reject & dependence \\
\hline $\mathbf{4 .}$ & 11,23 & 4 & 9,49 & 0,024 & yes & reject & dependence \\
\hline $\mathbf{5 .}$ & 0,37 & 3 & 7,81 & 0,945 & yes & accept & Independence \\
\hline
\end{tabular}

Source: authors

Explanatory note:

1. Are you familiar enough with the legislation concerning tourism and tourist guides?

2. Do you monitor development in Czech legislation regarding tourism and guides?

3. Do you monitor development in European legislation regarding tourism and guides?

4. How do you perceive legislative measures of the government and the MMR in terms of support of tourism field?

5. What is the impact of the Czech Government and the MMR's crisis legislation in tourism field?

From the figures in Table 4, we can state that there is existence of dependence between sex and monitoring of current development in European legislation regarding to tourism and tourist guides, however, a condition has been violated (expected values were lower than 1), thus, we cannot consider the dependence to be relevant. What is more, $\mathrm{H} 1$ on dependence has been verified in case of sex and following of Czech legislation on tourism in the field of guiding in times of pandemic. In case of attitude to legislative measures of the Czech Government and the MMR in terms of support of tourism 
in the time of the pandemic and sex, there was no dependence verified (the null hypothesis on independence has been accepted).

\section{Results}

The research proved that most of the respondents (82\%) declared that they were familiar enough with the legislation concerning tourism and tourist guides, $15 \%$ has an opposite opinion (Fig. 1). A high number of guides does not consider the present-day legislative regulation on guide assistance activities to be appropriate. Guides are mostly people with the tertiary-level education, many of whom understand the legal issues in their profession, hence, it is logical. Moreover, also their CR Guides Association (AP ČR) is, in transmitting of up-to-date information, relatively active.

Figure 1: Do you think that you are well aware of legislation concerning tourism and guides? (in \%)

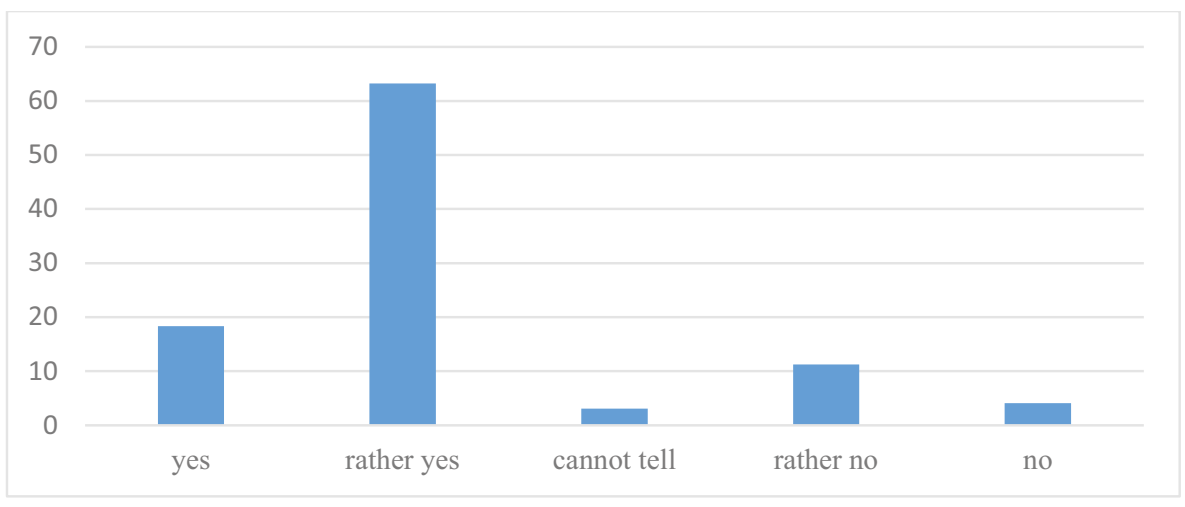

Source: authors

Current development in Czech legislation concerning tourism and guides is monitored approximately by $99 \%$ of the respondents (Fig. 2). On the other hand, with regards to open questions, which constituted the part of the research too, it has been shown that in fact, a proportion of people informed especially about current legislation is lower. Since we have also asked about new measures planned by the MMR, i. e. the Czech Tourist Guide Certification Card. Here, the familiarity has been lower and reached $66 \%$. This is somewhat surprising given how topical the issue is for the AP ČR and generally, especially for guides mainly from Prague. It may be explained by the fact that because of closing down of tourism industry in the Czech Republic, guides do not hurry to obtain the card. The implementation themselves i.e. of the Czech Tour Guide Certification Cards, the guides consider to be something which will not benefit guide activity regulation. The guides from Prague take their stand in the card-implementation issue more positively, which is understandable as the change of this state and the card-implementation has been the main initiative of the local authority in Prague, coordinated the AP ČR. 
It is essential to add that the research took place in November and December 2020 and that obligation to obtaining the certification card has been implemented since March 2021, and that guides were, until the end of February, exempted from paying the administrative fee.

Figure 2: Do you pay attention to the current situation in Czech legislation related to tourism and guides? (in \%)

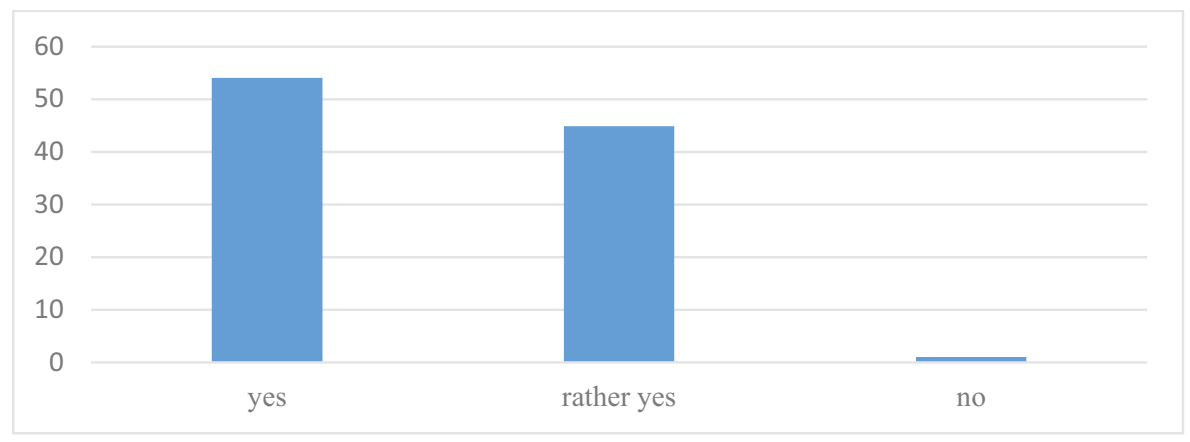

Source: authors

We have also asked respondents if they pay attention to the current European legislation regarding tourism and guides. The results, are, in comparison with their knowledge of Czech legislation, significantly different. A half of the respondents does not monitor current European legislation (Fig. 3).

Figure 3: Do you pay attention to the current situation in European legislation related to tourism and guides? (in \%)

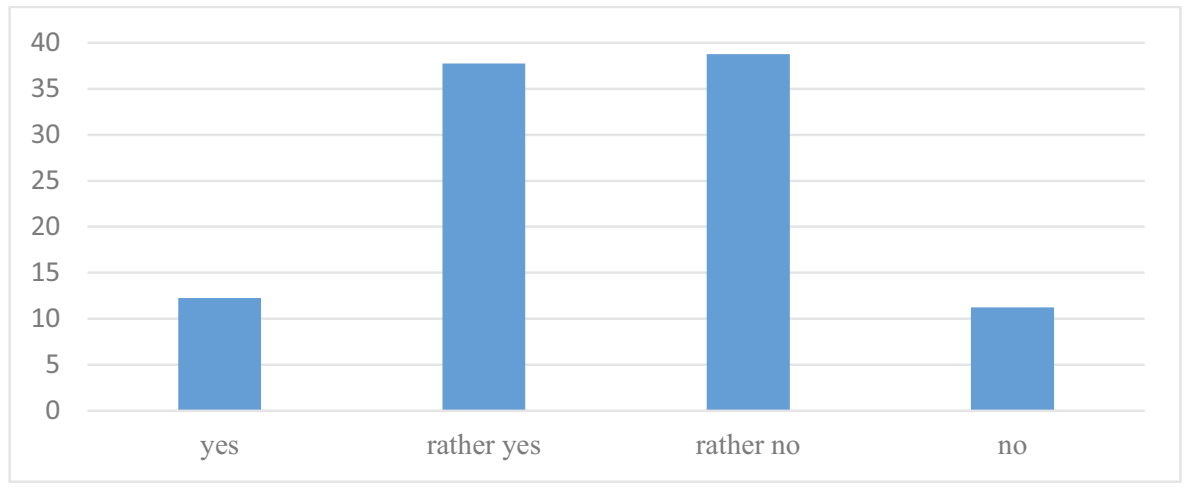

Source: authors

We have also studied how the respondents, in the time of the pandemic Covid-19, evaluate legislative measures of the Czech Government and the MMR concerning support of the tourism sector. Most of the respondents has a negative attitude to the legislative measures put into practice by the government and the MMR in the field of support of tourism in the time of pan- 
demic. Only more than one fifth can see the situation positively (Fig. 4). From additional interviews it is obvious that guides criticize especially the slow process of the support.

Figure 4: Evaluation of legislative measures of the Czech Government and the MMR in tourism sector (in \%)

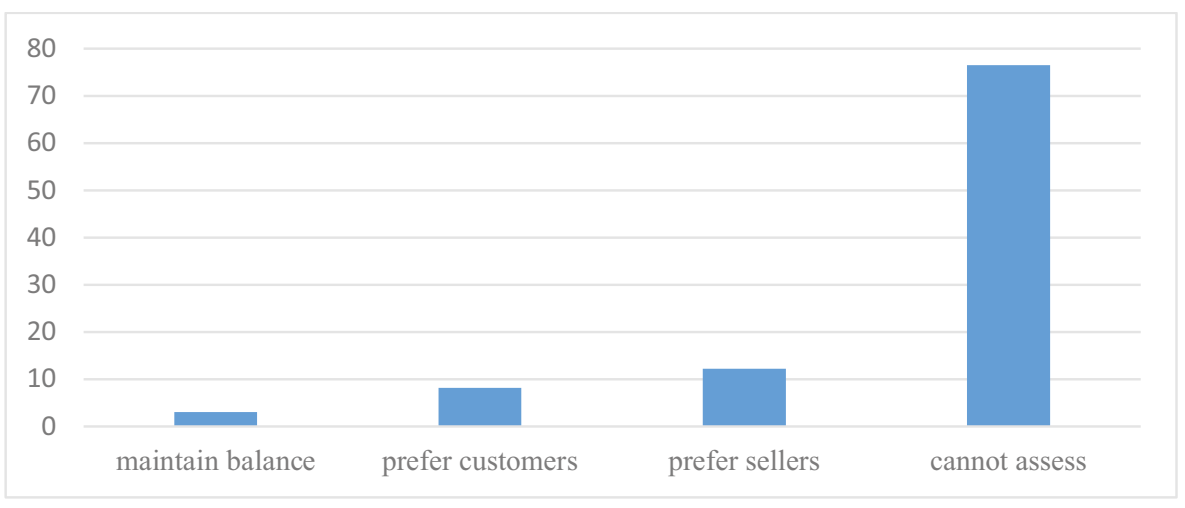

Source: authors

Although, the government began to pay out the compensations from 12 March 2020 at a few-weeks interval, which was not systemic aid. This did not happen within the programme Covid-19 Tourism until October 2020. Before that, critique had emerged a few times, even in media, coming from the AP ČR complaining that the government does not communicate with guides and does not take any effective steps to support the whole Tourist field, guides included. About $77 \%$ of the respondents is not able to assess the impact of the Czech Government's crisis legislation concerning Tourism. More than one tenth of them think that the crisis legislation sides organisers (i.e. travel agencies, and the like), $8 \%$ see the impact in siding with customers and only $3 \%$ mentioned that they are on balance between legitimate interests of entrepreneurs in tourism field (Fig. 5).

In open questions which formed part of our research activities, we have requested guides about the sort of aid they would welcome. Predominantly, answers focused on financial support (compensation of income losses), especially on their swiftness and administrative simplicity. Next, they noticed some rational State aid and the support of guide's retraining so as to have a greater chance to react in the flexible way to the new post-Covid period. Based on these answers, we have identified the most crucial aid factors: financial aid, more support from State and the local authority, social and insurance payment exemptions, promotion of tourism and guiding services supported by the State, and aid in the form of qualification and retraining. 
Figure 5: Effect of crisis measures of the Czech Government in the tourism field (in \%)

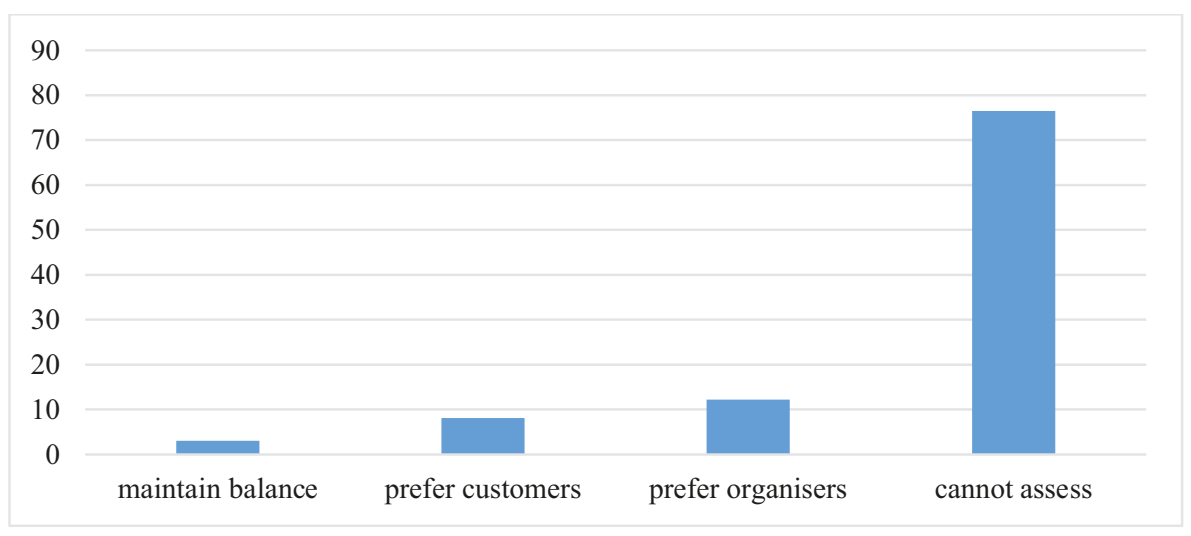

Source: authors

Concerning the noticed financial aid, apart from compensations, there also appeared the exemption or reduction related to payments of social security and health insurance. Interestingly, there was a certain stress on the support of up-skilling and an offer from job centres in the field of guides' training and their further education too. It can be assumed that part of them consider either cessation of their trade or taking up a second job and so on.

Besides measures linked to limitation of the work of guides in terms of the Covid-19, other factors of aid aimed at their functioning there occurred such phenomena as limitation or regulation of the number of new guides, in particular those without any qualification or knowledge, which according to them deteriorates image of this profession. Respondents also state aid with reasonable promotion of guides' activity who cooperate with guide agencies or travel agencies, reduction of an administrative character concerning demands related to the occupation, or the possibility of confluence of trade licence and record-taking and drawing of benefits from the job centre. Even though these stated measures are not related to the Covid-19, they are an interesting form of feedback to which more attention should be paid from the MMR's side.

In interviews, critique of government administration could be found quite often. This could be directed at both, insufficient financial aid as a result of cessation of their trade and problems with the complicated administrative character of this aid. There was repeatedly mentioned an example of illogical conditions under which, during the first wave of the pandemic when it was possible to reach the financial support from the MMR, guides had to prove 90 working days in the year 2020. However, it was not possible to reach that due to the fact that emergency state was declared in the Czech Republic on 12 March 2020. Then, in fact, tourism ceased to exist, hence, from the third month of the year, they managed to have a part-time job only. 
Quite considerable scepticism has been expressed towards measures not implemented so far and mistrust towards them as well as the government, which is related to an inappropriate conception of particular measures. As we know, the Czech Republic suffers from the Covid-19 considerably, which prevents entrepreneurs in the tourism field from conducting their businesses. Critique has been directed towards all of the fields of the current multi-level governance in the Czech Republic, i.e. also to an inappropriate crisis governance on both, municipal and regional levels.

\section{Discussion}

The results of the questionnaire survey proved that guides in the current Covid-19 pandemic regarded themselves as well informed when it came to legislation and a various kind of regulations and limitations concerning tourism. They also claim that they are interested in current development in the legislation, mainly the Czech one and partially in the European one too. In case of the EU norms, a half of our research sample does not follow the current legislation at all. Most of the respondents evaluate legislative measures implemented by the government of the Czech Republic and the MMR in tourism field in times of pandemic in a negative way. Only one fifth of the respondents consider the measures taken by the government in tourism and their impact as positive. This scepticism has been confirmed in additional investigation using the form of interviews. Majority of respondents were not able to say what impact financial and administrative measures had so far on the tourism sector as well as on guides alone, the most of respondents was not able to tell. Merely a tenth of the respondents can see effects of present measures taken by the Government, in siding entrepreneurs.

In accordance with the aim of the research, there were three research questions defined and hypotheses formulated. Dependence between sex and the factors examined was found with the use of the Independence Test ChiSquare. It is evident from the independence testing, we accept $\mathrm{H} 1$ hypothesis, thus, there is dependence between sex and:

- familiarization in terms of legislation concerning tourism and guides,

- monitoring of the current situation related to tourism and guides in European legislation,

- attitude detected in the process of evaluation of legislative measures of the government and the MMR related to the tourism sector support.

Conversely, there was no dependence found between monitoring of current development in the Czech legislation concerning the tourism and guides and dependence between sex and impact of crisis legislation of the Czech Government in the time of the pandemic.

This research has certainly its limitations of which we are, when interpreting results, well aware of. However, especially on the basis of quantitative investigation as well as additional qualitative research in the form of interviews, we 
will try, in spite of the fact mentioned, to formulate a few recommendations directed towards public administration and improvement of the current the tourism policy during the pandemic Covid-19. It is obvious that the communication of government administration with entities in tourism, in our case guides as well as measures implemented so far (financial and administrative) show some deficiencies.

Statistics show, entrepreneurs' trust in public administration is disappearing, which is apparent from our results. Trust in the State from the side of firms, entrepreneurs and sole traders, is generally disrupted in the Czech Republic, thanks to unclear and ambiguous decisions, and the frequent changes and insufficient communication from the side of the State. Although, key measures from the first wave like those aimed at sustaining jobs, for instance the fact that the Cabinet postponed the due date of taxes and insurance, extended them allowance, made cash for firms accessible and exempted them from paying part of taxes, thus, had worked, problems occurred during the second wave. These trends manifest themselves also in guides' responses and fall into the wider context.

It can be concluded that the current communication fails and that it is necessary to improve it sufficiently. Immediately also certain limitations in digitalization of public administration in the Czech Republic has been revealed, namely in insufficient interconnecting of different kinds of information systems and in monitoring. We consider setting up the effective monitoring system of the highest importance so that it enables to quickly address parties involved and access information. On such bases, particular administrative and also financial measures and other aid should be planned. It is possible to make use of technologies so as to automatically contact all parties interested. Monitoring systems thus, make it possible to see the feedback of parties interested during the crisis, which enables to adjust the strategy and tactics.

The trades shut-down, there is a zero income, most of costs go on, some companies even go bankrupt. Crisis legislation is in the Czech Republic - very widely formulated -as well as the State, really cannot compensate all of the losses which occur in the fight against the Coronavirus pandemic. But, the Government should have remembered this at the beginning and legislators should have advised how to declare the Emergency state as well as how to give orders and impose bans. A special approach of public administration then, should have been adopted to entrepreneurs in tourism. This field has been significantly affected, de facto - it has stopped. Yet, the aid has been insufficient and communication with the guides has not been prompt with respect to their vulnerability on a labour market. Our results, thus, should contribute to the rapid change in this matter and to plan measures carefully either short-term or long-term. 


\section{Conclusion}

The study shows that support from the state and the public administration plays a key-role in the Covid-19 pandemic. Furthermore, international organizations such as World Travel \& Tourism Council or the OECD point out the importance of state support to save the different professions in tourism (tourist guides included). Furthermore, the EU is aware of this fact too. It is interesting to watch debates led on this topic - who should get helped, what is an adequate compensation for the losses, etc. (Payne, Gil-Alana and Mervar, 2021).

First of all, we have to mention certain limitations which this study brings. Mainly, it presents the quick data, the data available until 20 December 2020, which is restricted only to the tourist guide sector. This data was gathered thanks to the CR Guide Association aid from whom we had been provided with the contacts to their members. We are aware of the fact that we do not cover the whole of the tourism sector (mainly, a much broader range of professions such as hotel-owners, etc.). We deal with the selected segment - small companies and individuals. We perceive our study as a case study focused on this sector mainly. Support of this sector will still be developing as long as the Covid-19 pandemic will continue, and it will be interesting to watch the development of these events.

However, what we can conclude even today from the OECD (2020) findings is that the lessons learned from this crisis will be - to build a more sustainable and resilient tourism economy for the future.

\section{Acknowledgment}

This paper was supported by the Ministry of Education, Youth and Sports Czech Republic within the Institutional Support for Long-term Development of a Research Organization in 2021 and by grant within Student grant competition at UJEP (2021-2022) - project No. UJEP-SGS-2021-63-002-2, "Current political problems of Central Europe." 


\section{References}

Aburumman, A.A. (2020). COVID-19 impact and survival strategy in business tourism market: the example of the UAE MICE industry. Humanit Soc Sci Commun, 141(7). https://doi.org/10.1057/s41599-020-00630-8.

Asociace průvodců (2020). Průvodci jsou pátý měsíc bez práce - Tisková zpráva. At <https://www.asociacepruvodcu.cz/novinky.php?id=204/>, accessed on 3 February 2021.

Bezkhlibna, A., But, T. and Nykonenko, S. (2018). Assessment of Tourism Industry Clustering Potential. Scientific Papers of the University of Pardubice, Series

D: Faculty of Economics and Administration, 26(2), 17-28.

Boksbergera, P.E. Biegerb, T. and Laesserb, C. (2007) Multi-dimensional analysis of perceived risk in commercial air travel. Journal of Air Transport Management, 13(2), pp. 90-96. https://doi.org/10.1016/j. jairtraman.2006.10.003

Chang, C. L., McAleer, M. and Ramos, V. (2020). A charter for sustainable tourism after COVID-19. Sustainability, 12(9), p. 3671. https://doi.org/10.3390/ su12093671.

Cartwright, R. (2000). Reducing the health risks associated with travel. Tourism Economics, 6(2), pp. 159-167. https://doi. org/10.5367/000000000101297550.

Chen, M.H., Jang, S.S. and Kim, W.G. (2007). The impact of the SARS outbreak on Taiwanese hotel stock performance: an event-study approach. International Journal of Hospitality Management, 26(1), pp. 200-212. https://doi. org/10.1016/j.ijhm.2005.11.004.

Chen, M.H. (2011). The response of hotel performance to international tourism development and crisis events. International Journal of Hospitality Management, 30(1), pp. 200-212. https://doi.org/10.1016/j. ijhm.2010.06.005.

Chen, S., Law, R. and Zhang, M. (2021). Review of research on tourism-related diseases. Asia Pacific Journal of Tourism Research, 26(1), pp. 44-58. https:// doi.org/10.1080/10941665.2020.1805478.

Čsú. (2020). Satelitní účet cestovního ruchu. At <https://www.czso.cz/csu/czso/ satelitni_ucet_cestovniho_ruchu/>, accessed 2 February 2021.

ČT 24, (2020). Rapidní propad v turistice. Meziročně v Česku ubylo pět milionů hostů. At <https://ct24.ceskatelevize.cz/ekonomika/3156633-rapidni-propadv-turistice-mezirocne-v-cesku-ubylo-pet-milionu-hostu/>, accesed on 2 February 2021.

ČT 24, (2021). Potrvá dlouho, než se turismus vrátí na starou úroveň, míní analytici. Byznysové cesty asi čeká útlum. At <https://ct24.ceskatelevize.cz/ ekonomika/3267130-potrva-dlouho-nez-se-turismus-vrati-na-starou-urovenmini-analytici-byznysove/>, accessed 4 February 2021.

EU Parliament, (2021). Covid-19: EU support for the tourism industry. At <https:// www.europarl.europa.eu/news/en/headlines/society/20200429STO78175/ covid-19-eu-support-for-the-tourism-industry>, accessed 15 March 2021.

Eichenauer, V. and Sturm, J-E. (2020). Die wirtschaftspolitischen Maßnahmen der Schweiz zu Beginn der Covid-19-Pandemie. Perspektiven der Wirtschaftspolitik 2020, 21(3), pp. 290-300. https://doi.org/10.1515/pwp2020-0027. 
Fangnan, C. et al. (2016). An overview of tourism risk perception. Natural Hazards, 82(1), pp. 643-658. https://doi.org/10.1007/s11069-016-2208-1.

Floyd, M. F. et al. (2004). The Effect of Risk Perceptions on Intentions to Travel in the Aftermath of September 11, 2001. Journal of Travel \& Tourism Marketing, 15(2/3), pp. 19-38. https://doi.org/10.1300/J073v15n02_02.

Fodoudi, P., Tabaghdehi, S. A. H. and Marvi, R. (2021). The gloom of the COVID-19 shock in the hospitality industry: A study of consumer risk perception and adaptive belief in the dark cloud of a pandemic. International Journal of Hospitality Management, 92, 102717. https://doi.org/10.1016/j. ijhm.2020.102717.

Gössling, S., Scott, D. and Hall, C. M. (2020). Pandemics, tourism and global change: A rapid assessment of COVID-19. Journal of Sustainable Tourism, pp. 1-20. https://doi.org/10.1080/09669582.2020.1758708.

Hajibaba, H., Boztuğ, Y. and Dolnicar, S. (2016). Preventing Tourists from Cancelling in Times of Crises. Annals of Tourism Research, 60, pp. 48-62. http://dx.doi.org/10.1016/j.annals.2016.06.003.

Hall, C. M. (2010). Crisis Events in Tourism: Subjects of Crisis in Tourism. Current Issues in Tourism, 13(5), pp. 401-417. https://doi.org/10.1080/13683500.201 0.491900 .

Hospodářské noviny, (2020). Služby hlásí propad tržeb o pětinu, hostů v hotelech ubylo o 83 procent, ukazují data Čsú. At <https://domaci.ihned. cz/c1-66800040-poskytovatele-sluzeb-zazili-nejvetsi-propad-za-poslednichpatnact-let-v-dubnu-a-kvetnu-se-prakticky-zastavil-prijezdovy-cestovni-ruch/>, accessed 22 February 2021.

Hossain, M. (2021). The effect of the Covid-19 on sharing economy activities. Journal of Cleaner Production, 280(1). https://doi.org/10.1016/j. jclepro.2020.124782.

Idnes. (2021). V Česku se loni ubytovalo 10,8 milionu turistů. Cizinců ubylo o tři čtvrtiny. At <https://www.idnes.cz/ekonomika/domaci/csu-turiste-cestovniruch-cesko.A210209_091917_ekonomika_rie/>, accessed on 5 February 2021.

Irozhlas.cz, (2020). Vláda představila novou pomoc pro podnikatele. ,Až ted' napravuje chyby, ' ř́ká ekonomický redaktor. At <https://www.irozhlas.cz/ ekonomika/podcast-vinohradska-12-vlada-koronavirus-podpora-podnikanijakub-horacek_2101210600_miz/>, accessed 3 February 2021.

Khalid, U., Okafor, L.E. and Burzynska, K. (2021). Does the size of the tourism sector influence the economic policy response to the COVID-19 pandemic? Current Issues in Tourism. https://doi.org/10.1080/13683500.2021.1874311.

Kock, F. et al. (2020). Understanding the COVID-19 tourist psyche: The Evolutionary Tourism Paradigm. Annals of Tourism Research, 85, p. 103053. 10.1016/j.annals.2020.103053.

Law, R. (2006). The Perceived Impact of Risks on Travel Decisions. International Journal of Tourism Research, 8(4), pp. 289-300. https://doi.org/10.1002/ jtr.576.

Lee, CC. and Chen, M.P. (2020). The impact of COVID-19 on the travel and leisure industry returns: Some international evidence. Tourism Economics. https:// doi.org/10.1177/1354816620971981.

MMR. (2020). Vláda schválila 500 milionů korun pro cestovní kanceláře, agentury a prưvodce. At <https://www.mmr.cz/cs/ostatni/web/novinky/vlada-schvalila500-milionu-korun-pro-cestovni-kan/>, accessed on 4 February 2021. 
Modlin, E. A., Alderman, D. H., and Gentry, G. W. (2011). Tour Guides as Creators of Empathy: The Role of Affective Inequality in Marginalising the Enslaved at Plantation House Museum. Journal of Tourism Studies, 11(1), pp. 3-19.

Nhuyen, B.N. and Thi, H.V.H. (2021). Impact of Covid-19 on Airbnb: evidence from Vietnam. Journal of Sustainable Finance \& Investment. https://doi.org/1 0.1080/20430795.2021.1894544.

Niewiadomski, P. (2020). COVID-19: From temporary de-globalisation to a rediscovery of tourism? Tourism Geographies, pp. 1-6. https://doi.org/10.1080/ 14616688.2020 .1757749$.

Novelli, M. et al. (2018). 'No Ebola...still doomed' - The Ebola-induced tourism crisis. Annals of Tourism Research, 70, pp. 76-87. https://doi.org/10.1016/j. annals.2018.03.006.

Novotný, L. (2021). Konec „deštníkářů“ v českých městech. Nová právní úprava činnosti turistických průvodců. Studia turistica, 12(1), pp. 36-45.

OECD, (2020). Mitigating the impact of the COVID-19 on tourism andsupporting recovery. At <https://www.oecd-ilibrary.org/docserver/47045bae-en.pdf?expi res $=1616666645 \&$ id $=i d \& a c c n a m e=$ guest\&checksum =FA01FC1B17AB5402D2 E78B81B75FB8FD>, accessed 2 February 2021.

Pak, A. et al. (2020). Economic Consequences of the COVID-19 Outbreak: the Need for Epidemic Preparedness. Frontiers in Public Health, 29(8), p. 241. https://doi.org/10.3389/fpubh.2020.00241.

Pappas, N. and Glyptou, K. (2021). Accommodation decision-making during the COVID-19 pandemic: Complexity insights from Greece. International Journal of Hospitality Management, 93. 10.1016/j.ijhm.2020.102767.

Payne, J.E., Gil-Alana, L.A. and Mervar, A. (2021). Persistence in Croatian tourism: The impact of COVID-19. Tourism Economics. https://doi. org/10.1177/1354816621999969.

Romagosa, F. (2020). The COVID-19 crisis: Opportunities for sustainable and proximity tourism. Tourism Geographies, 22(3), pp. 1-5. https://doi.org/10.10 80/14616688.2020.1763447.

Rosselló, J., Becken, S. and Santana-Gallergo, M. (2020). The effects of natural disasters on international tourism: A global analysis. Tourism Management, 79, p. 104080. https://doi.org/10.1016/j.tourman.2020.104080.

Sikiru, A.A. and Salisu, A.A. (2021). Hedging against risks associated with travel and tourism stocks during COVID-19 pandemic: The role of gold. International Journal of Finance \& Economics, Jan. 2021. https://doi. org/10.1002/ijfe.2513.

Shek, D. T. L. (2021). COVID-19 and Quality of Life: Twelve Reflections. Applied Research Quality Life 16, 1-11(2021). https://doi.org/10.1007/s11482-02009898-z.

Skare, M., Soriano, D.R. and Porada-Rochoń, M. (2020). Impact of COVID-19 on the travel and tourism industry. Technologicsl Forecasting and Social Change, 163, p. 120469. https://doi.org/10.1016/j.techfore.2020.120469.

Toanoglou, M., Chemli, S. and Valeri, M. (2021). The organizational impact of the Covid-19 crisis on travel perceived risk across four continents. Journal of Organizational Change Management. https://doi.org/10.1108/JOCM-122020-0369.

Týden.cz. (2020). Průvodcưm chybějí zakázky. Bez pomoci státu skončí. At <https://www.tyden.cz/rubriky/domaci/pruvodcum-chybeji-zakazky-bezpomoci-statu-skonci_546466.html/>, accessed 2 February 2021. 
UN. (2020). Policy Brief: COVID-19 and Transforming Tourism. At <https://unsdg. un.org/resources/policy-brief-covid-19-and-transforming-tourism/>, accessed 2 February 2021.

UNWTO. (2020a). COVID-19 Related Travel Restrictions: A Global Review for Tourism. Second Report as of 28 April 2020. At <https://webunwto.s3.euwest-1.amazonaws.com/s3fspublic/2020-04/TravelRestrictions - 28 April. $\mathrm{pdf} />$, accessed 2 February 2021.

UNWTO. (2020b). International Tourism and covid-19. At <https://www.unwto. org/international-tourism-and-covid-19/>, accessed 2 February 2021.

Wen, J. et al. (2020). Many brains are better than one: The importance of interdisciplinary studies on COVID-19 in and beyond tourism. Tourism Recreation Research, 1-4. https://doi.org/10.1080/02508281.2020.1761120

WTTC. (2021). Government COVID-19 Policies. At <https://wttc.org/COVID-19/ Government-Policies>, accessed 27 February 2021.

Zopiatis, A., Savva, C.S., and Lambertides, N. et al. (2019). Tourism stocks in times of crisis: an econometric investigation of unexpected nonmacroeconomic factors. Journal of Travel Research 58(3), pp. 459-479. https://doi.org/10. $1177 / 0047287517753998$. 